\section{Do Intratumoral and Peritumoral Apparent Diffusion Coefficient (ADC) Values Have A Role in the Diagnosis of Pediatric Brain Tumors?}

\author{
Intratümöral ve Peritümöral ADC (Apperent Diffusion \\ Coefficient) Değerlerinin Pediatrik Beyin Tümörlerinin \\ Tanısında Önemi Var mıdır?
}

Güleç Mert Doğan $\odot$ Ahmet Sığırcı $\odot$ Sevgi Taşolar $\odot$ Aslınur Cengiz $\odot$ Hilal Er Ulubaba $\odot$ Selami Çagatay Önal $\odot$ Neşe Karadağ $\odot$

\begin{abstract}
Objective: The motion of water particles within biological tissues, which is called random Brownian motion, is detected at the microscopic level by Diffusion-Weighted Imaging (DWI) sequence of Magnetic Resonance Imaging technique. The Apparent Diffusion Coefficient (ADC) calculated on DWI has been used for thediagnosis and grading of tumors. The purpose of this study was to evaluate of ADC values in the differential diagnosis of supratentorial and infratentorial pediatric brain tumors and to reveal the difference of peritumoral ADC measurements of pediatric patients from adult patients.

Method: All of the 56 pediatric patients included in this retrospective study had lesions $>1 \mathrm{~cm}$ in diameter on magnetic resonance images and all of the diagnosies were confirmed by histopathology. Intratumoral and peritumoral $A D C$ values and ratios were measured in diffusion- weighted magnetic resonance images.

Results: The $58.9 \%(n=33)$ of these tumors were supratentorial and $41.1 \%(n=23)$ of them were infratentorial. $A D C$ values and $A D C$ ratios were significantly lower in high-grade tumors than low-grade tumors $(p<0.05)$. Peritumoral ADC values in high-grade tumors were lower than low-grade tumors $(p<0.05)$. The cut-off value of the ADC ratio between these two groups was 1 and the ADC cut-off value was $1.1 \times 10^{3}$ / $\mathrm{mm}^{2} / \mathrm{s}$.

Conclusion: In the differentiation of low-, and high-grade pediatric brain tumors, cut-off values of $1.1 \times 10^{3}$ $/ \mathrm{mm}^{2} / \mathrm{s}$ for ADC Value and 1.0 for ADC Ratio may be useful. Although, peritumoral ADC values differ in children compared to the adult group, both intratumoral and peritumoral ADC values can aid in grading pediatric brain tumors.
\end{abstract}

Keywords: Apparent diffusion coefficient, brain tumor, magnetic resonance imaging

öz

Amaç: Rasgele Brown hareketi olarak adlandırılan biyolojik dokulardaki su parçacıklarının hareketi, Difüzyon Ağırlıklı Görüntüleme (DAG) tekniği ile mikroskopik düzeyde tespit edilebilir. DAG üzerinde hesaplanan Görünen Difüzyon Katsayısı (ADC) tümörlerin tanısı ve derecelendirmesinde kullanılmıştır. Bu çalışmanın amacı, supratentoriyal ve infratentoriyal pediatrik beyin tümörlerinin ayırıcı tanısında $A D C$ değerlerini değerlendirmek ve pediatrik hastaların peritümöral ADC ölçümlerinin yetişkin hastalardan farkını ortaya koymaktır.

Yöntem: Çalışmada, retrospektif olarak, beyin manyetik rezonans görüntülerinde, >1 cm'den büyük tümörü olan ve histopatolojik tanısı bulunan 56 hastanın difüzyon ağirlikli görüntülerinden intratümöral ve peritümöral Apparent Diffusion Coefficient (ADC) değerleri ve ADC oranları ölçüldü.

Bulgular: Tümörlerin \%58,9'u (n=3) supratentoriyal, \%41,1'i $(n=23)$ infratentoriyal olarak bulundu. ADC değerleri ve $A D C$ oranları yüksek dereceli tümörlerde düşük dereceli tümörlere göre anlamlı olarak düşük bulundu ( $p<0,05)$. Peritümöral $A D C$ değerleri de yüksek dereceli tümörlerde düşük dereceli tümörlerden daha düşük bulundu ( $p<0,05)$. Bu iki grup arasındaki $A D C$ oranının kestirim değeri 1 ve ADC değerinin cutoff değeri $1.1 \times 10^{3} / \mathrm{mm}^{2} / \mathrm{s}$ idi.

Sonuç: Düşük ve yüksek dereceli pediyatrik beyin tümörlerinin ayırımında ADC Değeri için $1,1 \times 10^{3} / \mathrm{mm}^{2} / \mathrm{s}$ ve $A D C$ Oranı için 1,0 kestirim değerleri yararlı olabilir. Peritümöral ADC değerleri çocuklarda yetişkin grubuna göre farklılık gösterse de, hem intratümöral hem peritümöral ADC değerleri pediyatrik beyin tümörlerinin derecelendirilmesine yardımcı olabilir.
Received/Geliş: 17.03 .2020 Accepted/Kabul: 19.06 .2020 Published Online: 22.12.2020

Güleç Mert Doğan İnönü Üniversitesi Tıp Fakültesi, Çocuk Radyolojisi Anabilim Dalı,

Malatya - Türkiye

- dr_gulecmert@hotmail.com ORCiD: 0000-0002-2305-9625

A. Sığırcı 0000-0001-9221-0002

S. Taşolar 0000-0002-9836-6814

A. Cengiz 0000-0002-9654-2298

Inönü Üniversitesi Tıp Fakültesi,

Çocuk Radyolojisi Anabilim Dalı, Malatya, Türkiye

H. Er Ulubaba 0000-0003-2124-4525 Inönü Üniversitesi Tıp Fakültesi, Radyoloji Anabilim Dalı, Malatya, Türkiye

S.ç. Önal 0000-0002-1216-2301 Inönü Üniversitesi Tıp Fakültesi, Beyin Cerrahisi Anabilim Dali, Malatya, Türkiye

N. Karadağ 0000-0003-0886-8122 Inönü Üniversitesi Tıp Fakültesi, Patoloji Ana.ilim Dalı, Malatya, Türkiye 


\section{INTRODUCTION}

In childhood the second most frequent tumors are the central nervous system (CNS) tumors ${ }^{(1)}$. Ninety percent of these CNS tumors are intracranial, and in pediatric patients posterior fossa is the specific localization for half of them ${ }^{(2)}$. Histopathology is the definitive diagnosis method for pediatric brain tumors (PBT). Medical imaging modalities can cause better survival rates by leading to better treatment choices, if the diagnostic accuracy of medical imaging increases and correlates with histopathology by preventing overtreatment and undertreatment ${ }^{(3)}$.

The motion of water particles within biological tissues, which is called random Brownian motion, is detected at the microscopic level by Diffusion-Weighted Imaging (DWI) sequence of Magnetic Resonance Imaging (MRI) technique. The Apparent Diffusion Coefficients (ADCs) calculated on DWI has been used for diagnosis and grading of tumors ${ }^{(4,5)}$. In previous studies, it has been shown that both cellularity and edema are reflected by ADC values ${ }^{(6)}$. Every surgical intervention, such as biopsy has significant risks; however, it may be possible to classify the tumors as low and high grade by using DWI without these risks.

Although there are many studies in the literature regarding the correlation of ADC values with the histopathological diagnosis of brain tumors, most of them have been conducted with adult patients. Also, most of the studies done in the pediatric group are related to the differentiation of the tumors in the infratentorial area ${ }^{(7,8)}$. In addition, there are fewer studies about the use of ADC value in the histopathological differentiation of supra- and infratentorial pediatric brain tumors and the researchers state that further studies should be done in this field ${ }^{(9-11)}$.

In addition to intratumoral ADC measurements, ADC values calculated from the peritumoral area, especially from the edematous area have been also used in the histopathological differentiation of brain tumors ${ }^{(12,13)}$. In all of these studies it is stated that higher $A D C$ values in the peritumoral zone are associated with lower ADC values in the intratumoral area. However, no study has been found on peritumoral ADC values calculated specifically for pediatric patients in the literature.

In this study, we aim to evaluate the ADC values in the differential diagnosis of supratentorial as well as infratentorial pediatric brain tumors and contribute to the literature.

We also aim to reveal the difference of peritumoral ADC measurements of these brain tumors of pediatric patients from brain tumors of adult patients.

\section{MATERIAL and METHODS}

\section{Patient selection:}

This retrospective study includes 56 pediatric patients, who had lesions at infratentorial or supratentorial localizations of the brain. All of the patients were diagnosed between 2012 and 2019 using MRI. The study is compliant with the Helsinki Declaration and was approved by the institutional ethics committee. All of the patients included in this study had lesions $>1 \mathrm{~cm}$ in diameter on MRI and all of the diagnoses were confirmed by histopathology. Cases having pseudotumors, cases without DWI/ADC signals in imaging protocol and cases not operated in our hospital and had not any histopathologic examination results were not included in our study.

\section{Magnetic resonance imaging}

All images in this study were obtained with 1.5-T (Siemens, Magnetom-Avanto) and 3-T (Siemens, Magnetom-Skyra) MRI both using a standard head coil. Pre-contrast and post-contrast T1-weighted images (T1-WI), T2-weighted images (T2-WI), Fluid Attenuated Inversion Recovery and DWI sequences were included in the MRI protocol. Only in 2 cases MR images did not have contrast- enhanced T1-W1 sequences. Diffusion gradients with $b$-values of 0 and $1000 \mathrm{~s} / \mathrm{mm}^{2}$ were applied in the $\mathrm{x}, \mathrm{y}$, and $\mathrm{z}$ directions. The ADC maps were generated automatically by the MR images.

\section{Regions of interest (ROIs)}

In our study, ADC values were evaluated by two pediatric radiologists, who did not know histopathological diagnoses. ADC values and ADC ratios were evaluated as described below. 
1. The evaluation was based on contrast-enhanced T1 images, except for 2 patients not having contrasted images.

2. In contrasted sections, calculations were made from the region corresponding to the most contrasted section of the tumor. Particular attention was paid not to make measurements from cystic and calcific areas. T2-WI was used in 2 patients not having contrasted images. Measurements were made from the region corresponding to the solid area at $\mathrm{T} 2 \mathrm{WI}$.

3. ADC value was obtained as follows: From each field measurements were made 3 to 5 times, and the average of them was designated as ADC value. Also each ROI was about 5 to $10 \mathrm{~mm}^{2}$ (Figures 1 and 3).

4. $A D C$ ratio was estimated as follows: One ADC measurement was made from normal parenchymal tissue symmetrical to the lesion and this value was

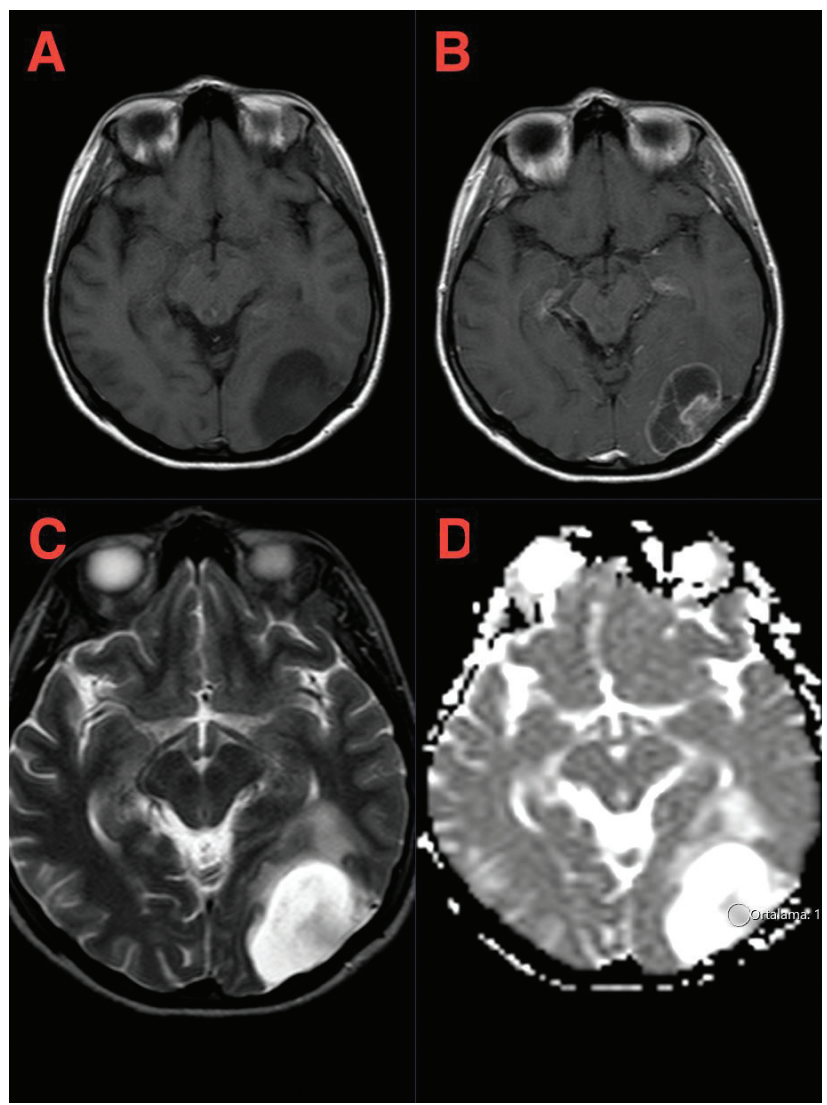

Figure 1. Brain MRI. A. T1W noncontrast. B.T1W contrastenhanced. C.T2W. D. ADC Images. Intratumoral ADC measurement of a 5 years old girl who has pilocytic astrocytoma at posterior parietal lobe. compared to the ADC value we calculated from the lesion. ROI was placed in the normal-appearing contralateral cerebellar gray matter for the infratentorial tumors and in the normal-appearing contralateral white matter for supratentorial tumors. (Figures 2B, and $4 \mathrm{~A}$ )

5. Peritumoral ADC values of all tumors were calculated by the same method. The measurements were done from approximately $1 \mathrm{~cm}$ periphery of the lesion, whether they contain peritumoral edema area or not (Figure 2A, Figure 4B).

6. "High-grade tumors" included WHO-III and IV tumors and "low-grade tumors" WHO-I and II tumors, which were classified histologically according to the WHO criteria ${ }^{(14)}$.

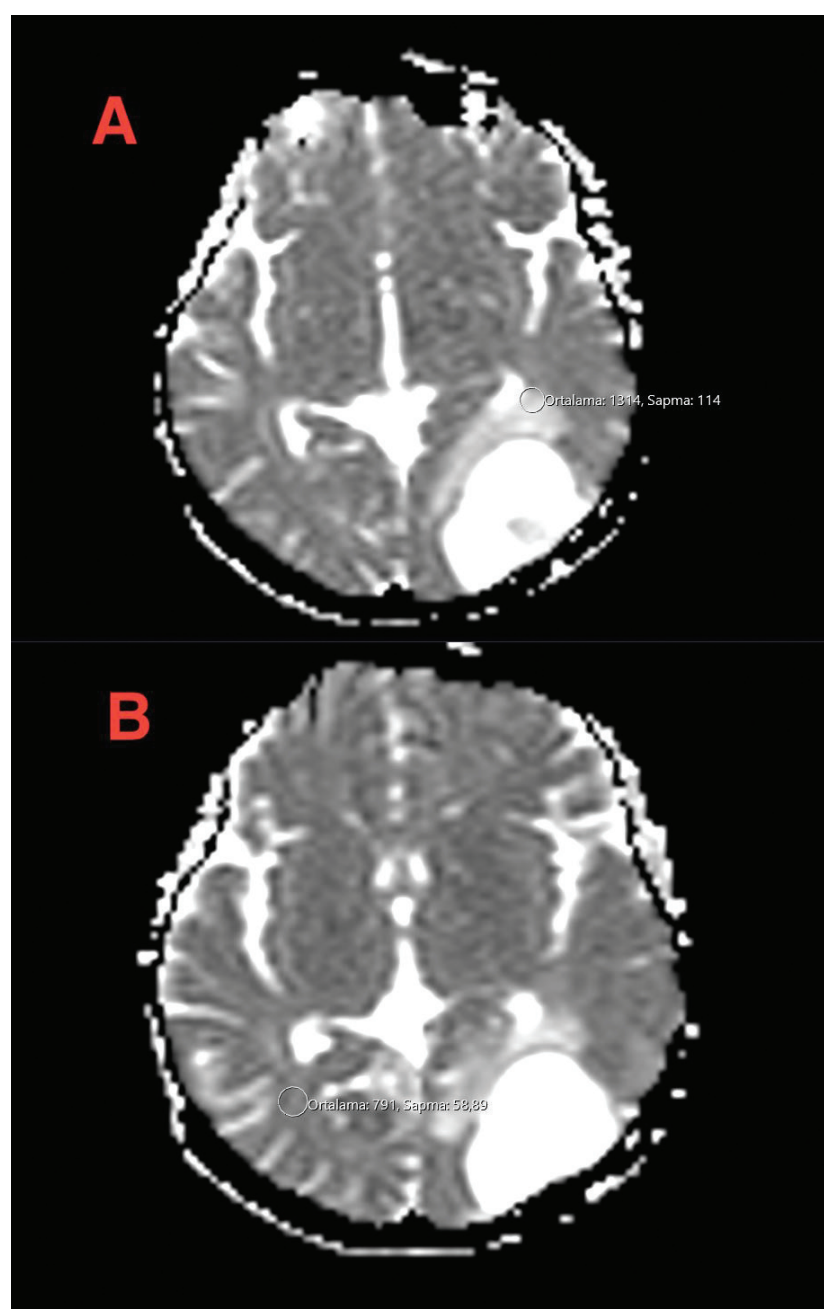

Figure 2. Brain MRI. A. ADC Image. Peritumoral ADC measurement. $B$. ADC Image. ADC measurement of the normal parenchymal tissue in the lesion symmetry. 


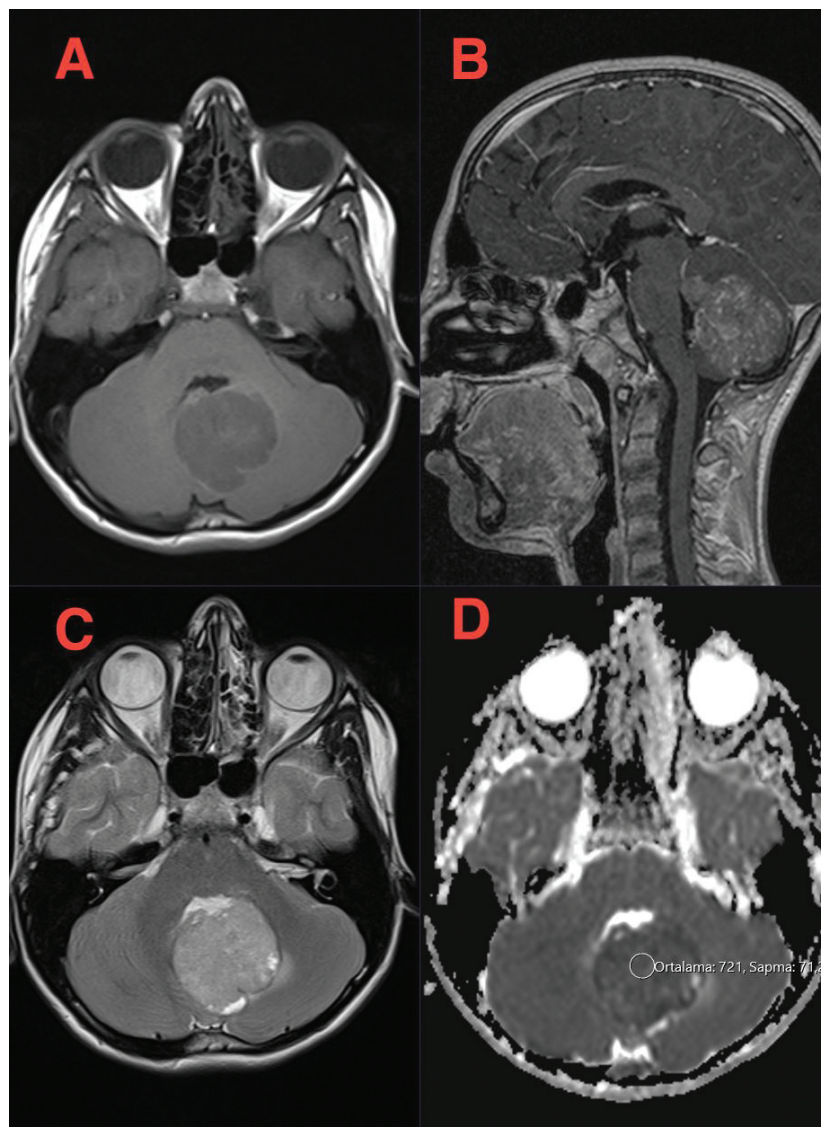

Figure 3. Brain MRI. A. T1W noncontrast B. T1W contrast enhanced C. T2W D. ADC Images. Intratumoral ADC measurement of a 3 years old girl. who has medulloblastoma at cerebellum.

\section{Statistics}

For the statistical evaluation of research data, SPSS software for Windows was used. The definition of quantitative data was made with mean +/- standard deviation (SD). Qualitative data was defined with numbers and percentages (\%). According to the results of Shapiro-Wilk normality test, Mann-Whitney $\mathrm{U}$ test and unpaired t test were used to compare quantitative data. the evaluation of qualitative data was done with the chi-square test and $\mathrm{P}<0.05$ was accepted statistically significant.

The proposed cut-off values selected were ADC values lying between the extremes of the two investigated groups (excluding outliers) in the interval where the values of the two groups did not overlap.

\section{RESULTS}

In this retrospective study, 56 pediatric cases with

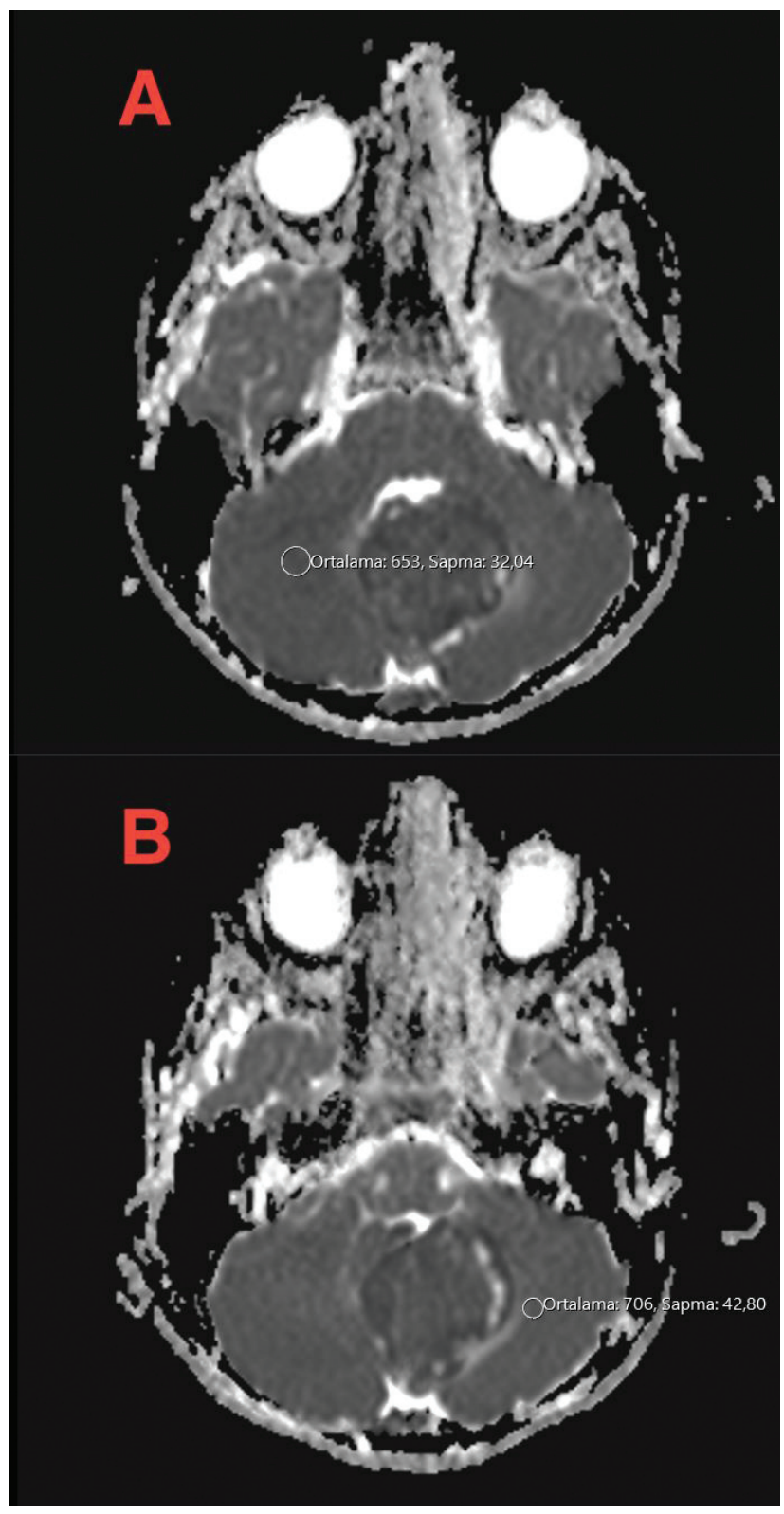

Figure 4. Brain MRI A. ADC Image: ADC measurement of the normal parenchymal tissue. in the lesion symmetry. B. ADC Image: Peritumoral ADC measurement.

a histopathologically confirmed PBT were evaluated. The mean age of the children was $9.23 \pm 5.31$ years; $51.8 \%(n=29)$ of them were female and $48.2 \%(n=27)$ of them were male. The $58.9 \%(n=33)$ of these tumors were supratentorial and $41.1 \%(n=23)$ of them were infratentorial. The list of the histopathologic types and specific localizations of the tumors evaluated in this study is summarized in Table 1 . The two most common tumor types, according to the World Health Organization (WHO) classification (14), 
were other astrocytic tumors and embryonic tumors.

Cystic, hemorrhagic components and contrast enhancement characteristics of tumors of our cases are listed in Table 2. Presence of cystic components in low-grade tumors and presence of hemorrhagic components in high-grade tumors were statistically, and significantly more frequently seen $(p<0.05)$, but the contrast enhancement pattern and the grade of the tumor did not correlate statistically significantly ( $p>0.05)$.

Table 1. The list of the histopathologic types and specific localizations of all tumors.

\begin{tabular}{|c|c|c|c|}
\hline Tumor Localization & Tumor Type/Grade & Who Grade Classification & Specific Localization \\
\hline \multirow[t]{8}{*}{ Supratentorial } & $\begin{array}{l}\text { Craniopharyngioma }(n=7) \\
\text { Low grade }\end{array}$ & $\begin{array}{l}\text { Tumors of the sellar } \\
\text { region }\end{array}$ & Suprasellar \\
\hline & $\begin{array}{l}\text { Gliosarcoma }(n=2) \\
\text { High grade }\end{array}$ & $\begin{array}{l}\text { Diffuse Astrocytic and } \\
\text { Oligodendroglial Tumors }\end{array}$ & Parietal \\
\hline & $\begin{array}{l}\text { Ganglioglioma }(n=2) \\
\text { Low grade }\end{array}$ & $\begin{array}{l}\text { Neuronal And Mixed } \\
\text { Neuronal-Glial Tumors }\end{array}$ & Frontotemporal, Temporal \\
\hline & $\begin{array}{l}\text { Immature Teratoma }(n=1) \\
\text { Low grade }\end{array}$ & Germ Cell Tumors & Frontotemporaparietal \\
\hline & $\begin{array}{l}\text { Mature Teratoma }(n=1) \\
\text { High grade }\end{array}$ & Germ Cell Tumors & Pineal Gland \\
\hline & $\begin{array}{l}\text { Langerhans Cell Histiocystosis } \\
(\mathrm{LCH})(\mathrm{n}=1) \\
\text { Low grade }\end{array}$ & Histiocytic Tumors & Suprasellar \\
\hline & $\begin{array}{l}\text { Pleomorphic Xantoastrocytoma }(n=1) \\
\text { Low grade }\end{array}$ & Other Astrocytic Tumors & Frontotempooral \\
\hline & $\begin{array}{l}\text { Glioneuronal Tumor }(n=1) \\
\text { Low grade }\end{array}$ & $\begin{array}{l}\text { Neuronal And Mixed } \\
\text { Neuronal-Glial Tumors }\end{array}$ & Frontotempooral \\
\hline \multirow[t]{4}{*}{ Infratentorial } & $\begin{array}{l}\text { Medulloblastoma }(n=7) \\
\text { High grade }\end{array}$ & Embryonal Tumor & Cerebellum \\
\hline & $\begin{array}{l}\text { Ependymoma }(n=2) \\
\text { Low grade }\end{array}$ & Ependymal Tumor & Cerebellum \\
\hline & $\begin{array}{l}\text { Atypical Teratoid Rhabdoid Tumor (ATRT) } \\
(n=1) \\
\text { High grade }\end{array}$ & Embryonal Tumor & Cerebellum \\
\hline & $\begin{array}{l}\text { Pilomyxoid Astrositoma }(n=1) \\
\text { Low grade }\end{array}$ & Other Astrocytic Tumors & Cerebellum \\
\hline \multirow[t]{5}{*}{ Supratentorial+Infratentorial } & $\begin{array}{l}\text { Pilocytic Astrocytoma }(n=21) \\
\text { Low grade }\end{array}$ & Other Astrocytic Tumors & $\begin{array}{l}\text { Suprasellar, Cerebellum, Occipital, } \\
\text { Temporal, Frontotemporal }\end{array}$ \\
\hline & $\begin{array}{l}\text { Hemangioblastoma }(n=4) \\
\text { Low grade }\end{array}$ & Mesenchymal Tumor & Cerebellum, Temporal \\
\hline & $\begin{array}{l}\text { Oligodendroglioma }(n=2) \\
\text { Low grade }\end{array}$ & $\begin{array}{l}\text { Diffuse Astrocytic and } \\
\text { Oligodendroglial Tumors }\end{array}$ & Cerebellum, Temporal, \\
\hline & $\begin{array}{l}\text { Anaplastic Ependymoma }(n=2) \\
\text { High grade }\end{array}$ & Ependymal Tumor & Cerebellum, Temporal \\
\hline & $\begin{array}{l}\text { Low grade: } 43 \\
\text { High grade: } 13\end{array}$ & & \\
\hline
\end{tabular}


Table 2. Comparison of low and high-grade tumors according to their cystic-hemorrhagic components and contrast enhancement characteristics.

\begin{tabular}{lccc}
\hline Tumor grade & $\begin{array}{c}\text { Cystic } \\
\text { component }\end{array}$ & $\begin{array}{c}\text { Hemorrhagic } \\
\text { component }\end{array}$ & $\begin{array}{c}\text { Contrast } \\
\text { involvement }\end{array}$ \\
\hline Low & $35(\% 81)$ & $8(\% 18)$ & $41(\% 95)$ \\
High & $6(\% 46)$ & $7(\% 53)$ & $12(\% 92)$ \\
& $p=0.015$ & $p=0.015$ & $p=0.094$ \\
\hline
\end{tabular}

The mean $A D C$ value of all tumors was $1.30 \pm 0.47 \times 10^{3} / \mathrm{mm}^{2} / \mathrm{s}$, and the mean ADC ratio was $1.63 \pm 0.61$. Anaplastic ependymoma had the lowest $\left(0.50 \times 10^{-3} / \mathrm{mm}^{2} / \mathrm{s}\right)$ and craniopharyngioma had the highest $\left(2.35 \times 10^{-3} / \mathrm{mm}^{2} / \mathrm{s}\right)$ ADC values (Table 3$)$. Neither ADC values, nor ADC ratios were statistically significant for the differentiation of histopathological types of all tumors according to WHO classification ( $p>0.05)$, although some of them could be differentiated such as pilocytic astrositoma and medulloblastoma. The supratentorial or infratentorial localization of the tumor did not create a significant statistical difference between the ADC values of tumors ( $p>0.05$ ).

The mean $A D C$ value was found $1.49 \pm 0.36 \times 10$ ${ }^{3} \mathrm{~mm}^{2} / \mathrm{s}$ in low-grade tumors and $0.68 \pm 0.12 \times 10^{-3} /$ $\mathrm{mm}^{2} / \mathrm{s}$ in high-grade tumors. The ADC values of highgrade tumors were significantly lower than the ADC values of the low-grade tumors $(p<0.05)$ (Table 4$)$. The ADC cut-off value of these two groups was $1.1 \times 10^{-3} / \mathrm{mm}^{2} / \mathrm{s}$. However, only 2 tumors didn't match with this value. One of them was the infratentorial oligodendroglioma and the other one was grade 1 pilocytic astrocytoma.

The mean $A D C$ ratios in low-, and high-grade tumors were $1.87 \pm 0.49$, and $0.85 \pm 0.11$, respectively. The ADC ratios of the high-grade tumors were significantly lower than those of the low-grade tumors $(p<0.05)$ (Table 4). The cut-off value of the ADC ratio between these two groups was 1 . The only patient that did not fit to this cut- off value was the case with the grade 1 pilocytic astrocytoma.

Table 3. Mean ADC Values and Mean ADC Ratios of all tumors.

\begin{tabular}{|c|c|c|c|c|}
\hline Tumors & $\begin{array}{c}\text { ADC Value Range } \\
\left(* 10^{-3} \mathrm{~mm}^{2} / \mathrm{s}\right)\end{array}$ & $\begin{array}{c}\text { Mean ADC Value } \\
\left({ }^{*} 10^{-3} \mathrm{~mm}^{2} / \mathrm{s}\right)\end{array}$ & ADC Ratio Range & Mean ADC Ratio \\
\hline Hemangioblastoma & $1.40-2.03$ & $1.72 \pm 0.25$ & $1.70-2.90$ & $2.30 \pm 0.49$ \\
\hline Medulloblastoma & $0.60-0.66$ & $0.63 \pm 0.22$ & $0.74-0.98$ & $0.87 \pm 0.08$ \\
\hline Ependymoma & $1.00-1.08$ & $1.04 \pm 0.56$ & $1.33-1.42$ & $1.37 \pm 0.6$ \\
\hline Anaplastic Ependymoma & $0.50-0.60$ & $0.55 \pm 0.07$ & $0.64-0.89$ & $0.76 \pm 0.06$ \\
\hline Pilocytic Astrocytoma & $0.78-1.84$ & $1.48 \pm 0.27$ & $0.90-2.40$ & $1.90 \pm 0.4$ \\
\hline Oligodendroglioma & $0.85-1.14$ & $0.99 \pm 0.20$ & $1.13-1.25$ & $1.19 \pm 0.08$ \\
\hline Craniopharyngioma & $1.37-2.35$ & $1.91 \pm 0.37$ & $1.7-2.86$ & $2.23 \pm 0.43$ \\
\hline Pilomyxoid Astrositoma & 1.16 & 1.16 & 1.61 & 1.61 \\
\hline Gliosarcoma & $0.77-0.90$ & $0.83 \pm 0.9$ & $0.70-1.00$ & $0.87 \pm 0.24$ \\
\hline Ganglioglioma & $1.23-1.35$ & $1.29 \pm 0.08$ & $1.55-1.73$ & $1.64 \pm 0.12$ \\
\hline Mature Teratoma & 1.21 & 1.21 & 1.27 & 1.27 \\
\hline Immature Teratom & 0.96 & 0.96 & 0.8 & 0.8 \\
\hline Atypical Teratoid Rhabdoid Tumor (ATRT) & 0.7 & 0.7 & 0.87 & 0.87 \\
\hline Langerhans Cell Histiocystosis (LCH) & 1.27 & 1.27 & 1.15 & 1.15 \\
\hline Pleomorphic Xantoastrocytoma & 1.18 & 1.18 & 1.22 & 1.22 \\
\hline Glioneuronal Tumor & 1.45 & 1.45 & 1.85 & 1.85 \\
\hline
\end{tabular}

Table 4. Comparison of low and high-grade tumors according to their ADC Values and ADC Ratios.

\begin{tabular}{lcccc}
\hline $\begin{array}{l}\text { Tumor } \\
\text { Grade }\end{array}$ & $\begin{array}{c}\text { ADC Value } \\
\text { Range } \\
\left(* 10^{-3} \mathbf{m m}^{2} / \mathrm{s}\right)\end{array}$ & $\begin{array}{c}\text { Mean ADC } \\
\text { Value } \\
\left(* 10^{-3} \mathrm{~mm}^{2} / \mathrm{s}\right)\end{array}$ & $\begin{array}{c}\text { ADC Ratio } \\
\text { Range }\end{array}$ & $\begin{array}{c}\text { Mean ADC } \\
\text { Ratio }\end{array}$ \\
\hline Low & $0.78-2.35$ & $1.49 \pm 0.36$ & $0.9-2.9$ & $1.89 \pm 0.49$ \\
High & $0.50-0.96$ & $\begin{array}{c}0.68 \pm 0.12 \\
p<0.001\end{array}$ & $0.64-1$ & $\begin{array}{c}0.85 \pm 0.11 \\
p<0.001\end{array}$ \\
\hline
\end{tabular}

Table 5. Comparison of pilocytic astrocytoma and medulloblastoma according to their ADC Values and ADC Ratios.

\begin{tabular}{lcccc}
\hline $\begin{array}{l}\text { Tumor } \\
\text { Type }\end{array}$ & $\begin{array}{c}\text { ADC Value } \\
\text { Range } \\
\left(* 10^{-3} \mathrm{~mm}^{2} / \mathrm{s}\right)\end{array}$ & $\begin{array}{c}\text { Mean ADC } \\
\text { Value } \\
\left(*-10^{-3} \mathrm{~mm}^{2} / \mathrm{s}\right)\end{array}$ & $\begin{array}{c}\text { ADC } \\
\text { Ratio }\end{array}$ & $\begin{array}{c}\text { Mean } \\
\text { ADC Ratio }\end{array}$ \\
\hline $\begin{array}{l}\text { Pilocytic } \\
\text { Astrocytoma }\end{array}$ & $0.78-1.84$ & $1.48 \pm 0.27$ & $0.9-2.40$ & $1.90 \pm 0.40$ \\
Medulloblastoma & $0.60-0.66$ & $\begin{array}{c}0.63 \pm 0.22 \\
\mathrm{p}<0.001\end{array}$ & $0.74-0.98$ & $\begin{array}{c}0.87 \pm 0.08 \\
p<0.001\end{array}$ \\
\hline
\end{tabular}


In the evaluation of the most common tumor types in our group such as pilocytic astrocytomas (other astrocytomas) and medulloblastomas (embryonic tumors), a statistically significant difference was found between the $A D C$ values and the $A D C$ ratios of these tumors $(p<0.05)$ (Table 5 ).

Mean peritumoral ADCvalueswere $1.04 \pm 0.41 \times 10^{-3} /$ $\mathrm{mm}^{2} / \mathrm{s}$ and $0.84 \pm 0.20 \times 10^{-3} / \mathrm{mm}^{2} / \mathrm{s}$ in the low-, and high-grade tumors, respectively (Table 6). While 12 of the 43 low-grade tumors had peritumoral edema, among 13 high-grade tumors, only one case with anaplastic ependymoma had peritumoral edema . There was no difference between the high-, and the low-grade tumors in terms of the presence of the peritumoral edema ( $p>0.05)$, but the difference was found to be significant in terms of the peritumoral ADC values $(p<0.05)$. Peritumoral ADC values of the low-grade tumors were higher than those of the high-grade tumors.

Table 6. Comparison of low and high- grade tumors according to their peritumoral ADC Values.

\begin{tabular}{lcc}
\hline Tumor Grade & $\begin{array}{c}\text { Peritumoral ADC } \\
\text { Value Range } \\
\left(* 10^{-3} \mathrm{~mm}^{2} / \mathrm{s}\right)\end{array}$ & $\begin{array}{c}\text { Peritumoral Mean } \\
\text { ADC Value } \\
\left(* 10^{-3} \mathrm{~mm}^{2} / \mathrm{s}\right)\end{array}$ \\
\hline Low & $0.65-2.40$ & $1.04 \pm 0.41$ \\
High & $0.68-1.50$ & $\begin{array}{c}0.84 \pm 0.20 \\
\mathrm{p}=0.029\end{array}$ \\
\end{tabular}

In our study all hemangioblastomas had peritumoral edema. The mean peritumoral ADC value of hemangioblastomas was $1.64 \pm 0.28 \times 10^{-3} / \mathrm{mm}^{2} / \mathrm{s}$ and the mean ADC value of pilocytic astrocytomas was $0.96 \pm 0.33 \times 10^{-3} / \mathrm{mm}^{2} / \mathrm{s}$. Also, pilocytic astrocytomas and hemangioblastomas differed in terms of having peritumoral edema and peritumoral ADC values were also statistically significantly different $(p<0.05)$. All hemangioblastomas but only $23.8 \%$ of pilocytic astrocytomas had a region of peritumoral edema.

\section{DISCUSSION}

In our study, the $A D C$ values and $A D C$ ratios of the high-grade tumors were found lower than of lowgrade tumors. However, only one patient who had a grade 1 astrocytoma as a pathological diagnosis was evaluated radiologically as high grade according to the signal features and contrast enhancement pattern in MRI.

Especially in recent years, studies on pediatric patients support our results ${ }^{(9,11)}$. Porto et al. ${ }^{(9)}$ retrospectively studied 36 supra-, and infra-tentorial PBTs. They grouped them according to their grades such as low and high-grade tumors and found that ADC values of low-grade tumors were higher than those of highgrade tumors. Their findings were similar with our study. Sahra et al. ${ }^{(11)}$ found statistically significant difference between tumor grades and ADC values.

In addition, in our research, the $A D C$ values and $A D C$ ratios differed statistically significantly between cases with medulloblastoma and pilocytic astrocytoma supporting the results of other studies $(15,16,7)$. Pilocytic astrocytoma had higher ADC values and $A D C$ ratios than medulloblastoma. Previously, Rumboldt et al. ${ }^{(17)}$ and Schneider et al. ${ }^{(7)}$ declared that children with infratentorial tumors had significantly lower ADC cut-off values in medulloblastoma compared to grade 1 astrocytoma. We had seen in our study that, differentiation of some tumors in terms of histopathological types could be done using $A D C$ values and $A D C$ ratios including pilocytic astrocytoma and medulloblastoma, but not all tumors (ie. pilocytic astrocytoma and hemangioblastoma) could not be differentiated using these parameters. Sahra et al. ${ }^{(11)}$ did not find any statistically significant difference between cell types and ADC values but detected statistically significant difference between tumor grades and ADC values similar with our study. In contrast to these findings, there are some studies in the literature showing that the differentiation between histopathologic cell types of brain tumor could be done using ADC values ${ }^{(17,18)}$.

DWI is a significant MRI sequence for some special brain lesions such as brain abscess, cerebral infarction, and brain neoplasms. In the diagnosis of brain tumors, DWI has been used in recent years. Some of the reported results are promising but there are also controversial results ${ }^{(17,9)}$. It has also been implied that calculating ADC values may improve grading of the tumor by evaluating characteristics of the tumor during the preoperative period ${ }^{(16)}$. 
Our study included both supra- and infra-tentorial tumors. In the literature, there are only few studies involving tumors of supra- and infra-tentorial area of pediatric patients ${ }^{(9,10)}$. In a retrospective study, Al-Sharydah et al. ${ }^{(10)}$ examined 80 supra- and infratentorial pediatric brain tumors, intratumoral ADC values were measured as whole lesion $A D C$ values. Other studies on pediatric brain tumors generally have examined posterior fossa or a specific localization in the brain. In a study including 19 pediatric patients aged $<1$ year with supratentorial brain tumors ${ }^{(19)}$, minimum $A D C$ values were evaluated according to the World Health Organization tumor grading system. The reported results showed that, when the ADC value was high, the tumor grade was low. In the study of Koral et al. ${ }^{(20)}$ performed in two different centers including 140 pediatric patients with cerebellar tumor, $A D C$ ratio of $\geq 1.8$ correctly differentiated ependymoma from pilocytic astrocytoma with a sensitivity and specificity of 0.80 . Also ependymoma was differentiated correctly from embryonal tumors when $A D C$ ratio was $<1.2$ with a sensitivity and specificity of 0.83 .

In our research, unlike previous studies, we calculated $A D C$ values not only for the area of peritumoral edema, but also ADC values of $1 \mathrm{~cm}$-wide peritumoral area of the lesion regardless of the presence of edema. were estimated. Previous studies included the adult patient group, and calculations were made from the T2- hyperintense edematous areas for the differentiation of lymphoma, metastasis and high-grade tumors ${ }^{(12,13,6)}$. In a study by Gaurav et al. ${ }^{(12)}$ peritumoral edema was found in 27 of 50 tumors and peritumoral infiltration could not be differentiated by ADC values. Caravan et al. ${ }^{(6)}$ also found that peritumoral $A D C$ values were more significant than intratumoral $A D C$ values among highgrade tumors and brain metastases. In a study including 16 adult patients with GBM, low-grade glioma and metastasis, Guzman et al. ${ }^{(13)}$ stated that peritumoral and intratumoral ADC values showed a negative correlation. Contrary to previous studies we found high peritumoral ADC values in low-grade tumors with high intratumoral ADC values. According to our results, $92 \%$ of tumors with peritumoral edema were low-grade tumors and $40 \%$ of all tumors were pilocytic astrocytoma. Pilocytic astrocytoma is known to have hyperintense edema; and radiologically it looks like a high-grade tumor. Therefore in pilocytic astrocytoma, higher intratumoral and peritumoral ADC values are obtained which may explain the rationale behind the different results we obtained. However, in the study performed by Luciana Porto et al. ${ }^{(21)}$ it was found that half of low-grade tumors, on the other hand, approximately $1 / 3$ of high-grade tumors had peritumoral edema in pediatric patients. This shows that childhood brain tumors may have different radiological features when compared with the adult group and further studies are needed in this field.

The calculated ADC values from the peritumoral areas of hemangioblastoma were higher than pilocytic astrocytoma. According the study of Malgorzata et al. ${ }^{(22)}$ the intratumoral mean and minimum ADC values of the hemangioblastoma and the pilocytic astrocytoma were close to each other. This may support the usability of peritumoral ADC values rather than intratumoral $A D C$ values for the differentiation between two tumor groups in childhood.

Our study had some limitations. It was a retrospective study. Our study enrolled limited number of patients, because we did not include the patients with a tumor in the brain MRI without a pathology report recorded in the system. Also the number of patients, especially of the rare tumor types, was low. In addition, the rates of high and low-grade tumors were not equal in our study, the number of lower grade tumors were higher. If this study is done prospectively with more patients, it may show the importance of ADC values in the tumor grading of cerebral and cerebellar tumors in childhood.

\section{CONCLUSION}

We can very easily calculate $A D C$ value and $A D C$ ratio. For this calculation, we only need to have Brain MR Images. In the differentiation of low and highgrade pediatric brain tumors, cut-off values of $1.1 \times 10^{-3} / \mathrm{mm}^{2} / \mathrm{s}$ for ADC and 1.0 for ADC Ratio may be useful. However, as previously described in the 
literature, these values should never be used alone in the determination of low- and high-grade tumors, because there can be a considerable overlap between tumor types. In addition, it should be kept in mind that both the peritumoral and intratumoral ADC values might be helpful for the differentiation between high- and low-grade pediatric brain tumors.

The authors declare no conflict of interest.

This study was presented previously at $2^{\text {nd }}$ International Dr. Behçet Uz Pediatric Congress on 04/03/2020 as an oral presentation.

Ethics Committee Approval: Inonu University Ethics Committee data:24-12-2019, No: 2019/198.

\section{Conflict of Interest: None.}

\section{Funding: None.}

Informed Consent: Informed consent has been taken.

\section{REFERENCES}

1. Legler JM, Gloeckler Ries LA, Smith MA, Warren JL, Heineman EF, Kaplan RS et al. Brain and other central nervous sys- tem cancers: recent trends in incidence and mortality. J Natl Cancer Inst. 1999;91:1382-90.

https://doi.org/10.1093/jnci/92.1.77

2. Dolecek TA, Propp JM, Stroup NE, Kruchko C. CBTRUS statistical report: primary brain and central nervous system tumors diagnosed in the United States in 2005-2009. Neuro Oncol. 2012;14(5):1-49.

https://doi.org/10.1093/neuonc/nos218

3. Panigrahy A, Bluml S. Neuroimaging of pediatric brain tumors: from basic to advanced magnetic resonance imaging (MRI). J Child Neurol. 2009;24(11):1343-65. https://doi.org/10.1177/0883073809342129

4. Bammer R. Basic principles of diffusion-weighted imaging. Eur J Radiol. 2003;45:169-84. https://doi.org/10.1016/S0720-048X(02)00303-0

5. Young GS. Advanced MRI of adult brain tumors. Neurol Clin. 2007;25:947-73. https://doi.org/10.1016/j.ncl.2007.07.010

6. Caravan I, Ciortea CA, Contis A, Lebovici A. Diagnostic value of apparent diffusion coefficient in differentiating between high-grade gliomas and brain metastases. Acta Radiol. 2018;59(5):599-605. https://doi.org/10.1177/0284185117727787

7. Schneider JF, Confort-Gouny S, Viola A, Le Fur Y, Viout P, Bennathan $\mathrm{M}$, et al. Multiparametric differentiation of posterior fossa tumors in children using diffusion-weighted imaging and short echo-time 1H-MR spectroscopy. J Magn Reson Imaging. 2007;26:1390-8. https://doi.org/10.1002/jmri.21185

8. Gimi B, Cederberg K, Derinkuyu B, Gargan L, Koral KM, Bowers DC, et al. Utility of diffusion coefficient ratios in distinguishing common pediatric cerebellar tumors. Acad Radiol. 2012;19:794-800.

https://doi.org/10.1016/j.acra.2012.03.004
9. Porto L, Jurcoane A, Schwabe D, Kieslich M, Hattingen E. Differentiation between high and low grade tumours in paediatric patients by using apparent diffusion coefficients. Eur J Paediatr Neurol. 2013;17:302-7. https://doi.org/10.1016/j.ejpn.2012.12.002

10. Al-Sharydah AM, Al-Arfaj HK, Al-Muhaish HS, Al-Suhaibani SS, Al-Aftan MS, Almedallah DK, et al. Can apparent diffusion coefficient values help distinguish between different types of pediatric brain tumors? Eur J Radiol Open. 2019;6:49-55. https://doi.org/10.1016/j.ejro.2018.12.004

11. El-Salam SM, Mokhtar O. Diagnostic accuracy of diffusion weighted imaging in evaluation of high and low grade pediatric brain tumors. Medical Journal of Cairo University. 2019;87:1877-83.

https://doi.org/10.21608/mjcu.2019.54033

12. Gaurav Bhandari. Role of diffusion weighted MRI in intraaxial brain tumours. Sch J App Med Sci. 2016; 4(6D):2111-9. https://doi.org/10.21276/sjams.2016.4.6.49

13. Guzman R, Altrichter S, El-Koussy M, Gralla J, Weis A, Barth A. Contribution of the apparent diffusion coefficient in perilesional edema for the assessment of brain tumors. J Neuroradiol. 2008;35(4):224-9.

https://doi.org/10.1016/j.neurad.2008.02.003

14. Louis D.N, Perry A, Reifenberger G, von Deimling A, FigarellaBranger A, WK, et al. The 2016 World Health Organization classification of tumors of the central nervous system: a summary. Acta Neuropathol. 2016;131:803-20. https://doi.org/10.1007/s00401-016-1545-1

15. Yamasaki F, Kurisu K, Satoh K, Arita K, Sugiyama K, Ohtaki M. Apparent diffusion coefficient of human brain tumors at $M R$ imaging. Radiology. 2005;235:985-91. https://doi.org/10.1148/radiol.2353031338

16. Kan P, Liu JK, Hedlund G, et al. The role of diffusion-weighted magnetic resonance imaging in paediatric brain tumours. Childs Nerv Syst. 2006;22:1435e9. https://doi.org/10.1007/s00381-006-0229-x

17. Rumboldt Z, Camacho DL, Lake D, Welsh CT, Castillo M. Apparent diffusion coefficients for differentiation of cerebellar tumors in children. AJNR Am J Neuroradiol. 2006;27:1362136. PMID: 16775298.

18. Gauvain KM, Mckinstry RC, Mukherjee P, Perry A, Neil JJ, Kaufman BA, Hayashi RJ. Evaluating pediatric brain tumor cellularity with diffusion-tensor imaging. Am J Roentgenol. 2001;177:449-54. https://doi.org/10.2214/ajr.177.2.1770449

19. Kralik SF, Taha A, Kamer AP, Cardinal JS, Seltman TA, Ho CY. Diffusion imaging for tumor grading of supratentorial brain tumors in the first year of life. Am J Neuroradiol. 2014;35:81523. https://doi.org/10.3174/ajnr.A3757

20. Koral K, Alford R, Choudhury N, Mossa-Basha M, Gargan L. Applicability of apparent diffusion coefficient ratios in preoperative diagnosis of common pediatric cerebellar tumors across two institutions. Neuroradiology. 2014;56(9):781-8. https://doi.org/10.1007/s00234-014-1398-z

21. Porto L, Jurcoane A, Schwabe D, Hattingen E. Conventional magnetic resonance imaging in the differentiation between high and low-grade brain tumours in paediatric patient. J Paediatr Neurol. 2014;18:(1):25-9. https://doi.org/10.1016/j.ejpn.2013.07.004

22. Malgorzata NM, Zimny A, Bladowska J, Czarnecka A, Sąsiadek $M$. The role of diffusion and perfusion magnetic resonance imaging in differentiation of hemangioblastomas and pilocytic astrocytomas. J Radiol. 2018;83:e197-e203. https://doi.org/10.5114/pjr.2018.75870 